\title{
Historical Descriptions of Multiple Sclerosis
}

The Stories of Augustus D'Este and The Journal of a Disappointed Man

\author{
J.M.S. Pearce \\ Emeritus Consultant Neurologist, Department of Neurology, Hull Royal Infirmary, Hull, UK
}

\section{Key Words}

Multiple sclerosis $\cdot$ Charcot's disease $\cdot$ Spinal cord

\begin{abstract}
Modern understanding of multiple sclerosis is firmly founded on the labours of many neuroscientists of the last two centuries. The cost of the disease to its victims is nowhere better displayed than in their personal accounts of their illnesses. Two figures stand out: the highborn aristocrat, Augustus D'Este and his diaries of the early 19th century and the courageous if histrionic Bruce Frederick Cummings in the early 20th century. This paper cannot do justice to their major contributions, but seeks to summarise them to give the flavour of their symptoms, disabilities and the way they were regarded by doctors and the people at large. The early medical studies of Carswell, Cruveilhier, Charcot and many others are briefly reviewed as relevant settings to these personal histories.
\end{abstract}

Copyright $\odot 2005$ S. Karger AG, Base

\section{The Diaries of Augustus D'Este (1794-1848)}

The best known and possibly the first patient's description of multiple sclerosis (MS) is to be found in the diary of Sir Augustus D'Este, grandson of King George III. Be- tween 1822 and 1848, his diaries and almanac for 18471848 , contain a personal chronicle, which has been widely accepted as portraying MS [1].

In the Victoria and Albert museum resides a watercolour on ivory: Portrait of an Unknown Boy by Richard Cosway R.A. Principal Painter to his Serene Highness the Prince of Wales. This boy has traditionally been called 'Frederick Augustus D'Este'.

He was born on January 13th 1794, 9 months after his parents - Lady Augusta Murray, daughter of John, 4th Earl of Dunmore, and Prince Augustus Frederick, Duke of Sussex, sixth son of King George III of the House of Hanover - had married in Rome. Augusta was never recognized by the King and was denied the title of Duchess. A violation of the Royal Marriage Act was subsequently declared and the marriage annulled by George III.

In December 1822, when he was 28 years old, Augustus suffered an attack of retrobulbar neuritis. In successive years, he noted progressive weakness, numbness, difficulty in walking, painful spasms and depression - all typical of MS. Although he was aged 54 when he died, no formal diagnosis was made, but 'the meticulous notes in his diary justify a posthumous diagnosis' [2].

The surviving part of his diary begins with a description of bilateral optic neuritis, which developed:

'In the month of December 1822 I travelled from Ramsgate to the Highlands of Scotland for the purpose of passing some days with a Relation for whom I had
Fax +41613061234 E-Mail karger@karger.ch www.karger.com
(C) 2005 S. Karger AG, Basel

Accessible online at:

www.karger.com/ene 
the affection of a Son. On my arrival I found him dead ... Shortly after the funeral I was obliged to have my letters read to me, and their answers written for me, as my eyes were so attacked that when fixed upon minute objects indistinctness of vision was the consequence: Until I attempted to read, or to cut my pen, I was not aware of my Eyes being in the least attacked. Soon after, I went to Ireland, and without anything having been done to my Eyes, they completely recovered their strength and distinctness of vision ...'

Optic neuritis recurred in 1826 [3]. He then suffered episodes of diplopia and weakness in the legs with perineal numbness in 1827 , after which he was never able to run fast or dance. During 1828, he had unpleasant sensory symptoms and fatigue but continued with his military career until developing urinary retention; he became constipated, had a single episode of faecal incontinence and found himself to be impotent whilst attempting the aforementioned commercial encounter. He subsequently chronicles visits to European spas, medical opinions and treatments suggested. Presumably, missing diary parts disclosed other events, because by 1843 [3] D'Este relates ataxia, spasms at night and numbness below his waist. In the same year, he had symptoms suspicious of transient brain stem demyelination. Then followed a slow progressive course with relapses and remissions. Ultimately he lost the use of his arms and was paralysed. Having had symptoms periodically for 26 years, in December 1848 he finally succumbed. The cited details, recorded in his diaries of this protracted illness are preserved by the work of Douglas Firth [1].

\section{The Journal of a Disappointed Man}

Until Augustus D'Este's diary was revealed in 1948 by Firth, the best known personal account of MS was The Journal of a Disappointed Man published on 31st March 1919 by 'WNP Barbellion'. This pseudonym concealed the identity of Bruce Frederick Cummings (1889-1919) who recorded:

'The surname is that of the proprietor of a chain of sweetshops with branches South Kensington, Bond Street and elsewhere; the initials stand impishly for Wilhelm Nero Pilate - "the world's three greatest failures".'

\footnotetext{
${ }^{1}$ Eric Bond Hutton's The Quotable Barbellion (Gerrards Cross, Alderbourne Books, 2000) provides an excellent source of his life and work. See also: http:// www.geocities.com/barbellion/index.html.
}

Cummings was born at 14 Cross Street, Barnstaple, son of a Tory journalist. He was a naturalist and worked on lice at the British Museum's Department of Natural History, without enthusiasm or enjoyment. Having begun a personal journal when aged thirteen, he continued it - gradually moving from dry scientific notes to a more personal, literary style. But he had meanwhile developed symptoms of MS.

On 26th April 1913, aged 24, Barbellion first records in his diary that his speech and right side are impaired and believes that he must have locomotor ataxy; he consulted Dr. Henry Head who seems to have had similar suspicions. Over the next 2 years, he relates further fluctuating symptoms, recognisable as demyelination. On 11 September 1915, he married Eleanor Benger, a fashion artist, who was secretly informed of his illness during their engagement. He saw other neurologists but no definite diagnosis was disclosed. However, rejected when enlisting for service in 1917, he read on the medical certificate of his doctor that MS had been diagnosed and communicated to his family [3]. He consulted Sir Thomas Allbutt's celebrated book System of Medicine that contained an excellent section on MS by Risien Russell.

According to Firth, learning the true nature of his illness placed Barbellion in a rather relaxed state, released from his former self-obsession and ambition. Temporarily restored to health, he began again to contemplate a number of zoological projects. Unfortunately whilst studying in the library he was dismayed by reading an enormous quarto memoir The Histology of Disseminated Sclerosis by James W. Dawson [4] the most comprehensive account of the pathology of MS. His imagination excited by increasing limb paresis and paraesthesiae in the hands, he writes in his diary (January 1917):

'the millions of bacteria gnawing away my precious spinal cord'.

He also came across the papers of Pierre Marie, which further disturbed him. At this late stage he longed for his past excursions into natural history, and recorded that he could not avoid comparing his own sad plight with that of unaffected healthy people around him. He writes despairingly of his inner thoughts, rehearsing dialogues, which briefly fortified him. On July 5th, 1917, he wrote:

'Why this deliberate, slow-moving malignity? Perhaps it is a punishment for the impudence of my desires. I wanted everything so I get nothing ... I am not offering up my life willingly - it is being taken from me piece by piece, while I watch the pilfering with lamentable eyes.' 
After 4 years of such misery and self-analysis, he displayed another aspect of his personality by dramatically recording in his diary, the final entries of 1917:

'October 12th: ... I have wept and enjoyed, struggled and overcome, and when the hour comes I shall be content to die.

October 14th to 29th: miserable.

October 21st: self disgust. Finis. Barbellion died on December 31st (1917).'

Like Mark Twain, on January 1st 1918, Barbellion had prematurely announced his death so that he might enjoy reading posthumous notices of his book.

Eighteen months late he did die on 22nd October 1919 at Camden Cottage (now a Chinese restaurant), Tatling End, Gerrards Cross - his home for the past 2 years. The October 12th entry in his controversial Journal provides a suitable epitaph:

'I am only twenty-eight, but I have telescoped into those few years a tolerably long life: I have loved and married, and have a family; I have wept and enjoyed, struggled and overcome, and when the hour comes I shall be content to die.'

The Journal of a Disappointed Man (Chatto and Windus, March 1919) was variously greeted: with undisguised contempt, damned as immoral, or acclaimed a work of genius, hailed as a masterpiece. It was also described as 'a wonderful record of a great spirit and a great fight' and 'one of the most extraordinary human documents that have ever been penned'. The first edition contained a preface by H.G. Wells. Many regard it as a minor classic of English literature.

\section{Clinicopathological Beginnings: Carswell, Cruveilhier and Charcot}

McDonald [5] records the 'first recognised' medical description of MS was written in 1840 by McKenzie [6] in a 23-year-old man who

'... was admitted into St. Bartholomew's Hospital, on account of a palsy of his limbs', which had evolved progressively over the preceding six months. He had, at the commencement of his illness, '... a (progressive) confusion of vision (so that) he could discern no object distinctly'.

McKenzie describes how he was incontinent and was developing an asymmetric weakness of the arms and dysarthria. After 3 weeks in hospital and frequent purges he began to improve. After 2 months

Historical Descriptions of Multiple Sclerosis
'... he could move his hands and arms nearly as well as ever; and his eyesight was so much improved that he could read a newspaper ... the functions of the bladder were completely restored; (and) his speech became articulate'.

In 1837 Sir Robert Carswell (1793-1857) [7] investigated the pathology of MS, based on studies he made in Paris. Carswell's training began in Glasgow. He was the first professor of Pathological Anatomy at University College, London (1828), and later personal physician to the King of the Belgians. Spillane described him as an 'artistpathologist'. He did not attempt any clinicopathological correlations, and although he clearly depicted demyelinating lesions, their significance was not appreciated:

'I could not ascertain that there was anything in the character of the paralysis or the history of the cases to throw any light on the nature of the lesion found in the region of the spinal cord.'

The preface to Carswell's atlas is dated 15 December 1837. The legends describe:

'a peculiar diseased state of the chord and pons to the grey substance'.

'FF. Isolated points of the pons Varolii of a yellowish brown colour; GGG. Patches of the same kind on the spinal chord, all of them occupying the medullary substance which was hard, semitransparent and atrophied ... $\mathrm{H}$ affects the right olivary body; $\mathrm{K}$ softening of a portion of the chord. Figure 4, A and B, ... cord show that the discolouration commences on the surface of the white and extends into the grey substance.'

Jean Cruveilhier (1791-1874), the first professor of Pathological Anatomy in Paris, is credited by Charcot as having first illustrated the lesions of MS in the second tome of his pathological atlas which bears the title date 1835. But the 40 livraisons of this work were published separately in parts and documentary evidence contained within the volume 2 , parts 22 and 23 indicates that the putative case of MS cannot have appeared earlier than 1841 [3].

Spillane regarded Cruveilhier as 'the prince of these physician-pathologists'. He observed and described [8] multiple lesions - 'reddish grey islets,' and referred to their entire appearance 'a grey degeneration of the columns of the spinal cord ... grey degeneration in the cord, brainstem and cerebellum' [9], very similar to Carswell's observations. Cruveilhier and Carswell worked independently but their illustrations appeared almost simultaneously. There is debate as to which illustration was made first. However, Cruveilhier's version, was not published until 1842 . He was the first to record the clinical history

Eur Neurol 2005:54:49-53 
of a patient later found to have demyelinating lesions. His

notes describe a woman who:

'had been ill six years without cause ... she noticed that

the left leg resisted her will to such a degree that she

fell in the street'.

He described how over several years, the patient developed weakness of both legs and arms, spasms, difficulty in swallowing and visual disturbances. From this he diagnosed 'a lesion of the upper portion of the spinal cord'.

Friedrich von Frerichs [2], with his pupil Valentiner, first (1849) recognised remissions as a characteristic. He also described nystagmus as a symptom of the disease. In 1863 Rindfleisch [10] too, noticed:

'Consistently a blood vessel was present at the centre of each lesion.... All this leads us to search for the primary cause of the disease in an alteration of individual vessels and their ramifications; All vessels running inside the foci, but also those which traverse the immediately surrounding but still intact parenchyma are in a state characteristic of chronic inflammation.'

Charcot also extolled the works of Frommann, Ordenstein, Bouchard and Vulpian [11].

\section{Charcot's Disease}

'It is Charcot and Vulpian who deserve the honour of having given to insular sclerosis the dignity of an anatomical and clinical existence in 1866 and of describing in a masterly way the symptoms and pathological anatomy of the disease.' (Pierre Marie [12])

Thus, the illness was not generally recognised in France $[13,14]$. Charcot (1825-1893) gave a full clinico-pathological exposition in 1868 . The picture drawn by Charcot and presented in Ordenstein's 1867 Parisian thesis was the first to display specific ventricle-based lesion expansions into the cerebral hemispheres. It forms the earliest and still unsurpassed précis of the explicit pathology of MS both in cord and brain.

Charcot's original captions to his images included: 'Sclerosed plaque affecting the [upper] wall of the lateral [cerebral] ventricle' - reaching, up to one centimetre of the ventricular border (figure 1, a, a). 'Sclerosed nuclei', exposed by sectioning the pons parallel to its anterior front (fig. 2, a, a). 'Sclerosed plaques of pons and spinal bulb' (fig. 3, a, a) and 'ependyma' of the brain's fourth ventricle (fig. $3, b, b$ ).

His was the first comprehensive account of MS [15]. Charcot recognised examples of the cephalic form, spinal form and the mixed or cerebrospinal form. He elegantly detailed their symptomatology, in which he described brain and spinal cord specimens affected by sclerotic plaques. Microscopically he documents in his Lectures, 'fatty granular bodies' in the medullary matter and the destruction of the 'myeline cylinder' in the sclerosed nodule:

'nerve tubes...atrophy goes on at the expense of the medullary sheath for the axis cylinder has preserved its normal diameter ...' [11].

With Bouchard, he was keen to provide more specific histology; thus, they emphasized the preserved axons in the centre of the demyelinated plaque. This explicated the absence of secondary axonal degeneration. In 1855 Charcot knew of at least 3 patients with sclerose en plaques. Charcot presented them to the Société Médicale des Hôpitaux on 9th May 1866, but Vulpian was the modest author who, declared that Charcot had described sclerosis of the lateral columns to the society in the previous January. Charcot's lectures referred to disseminated sclerosis, but he named the disease le sclerose en plaques [16]. Julius Althaus attached the eponym Charcot's disease in 1877 .

In 1868 Charcot in his lecture says:

'Even to-day I do not believe that disseminated sclerosis is known in England.'

In 1875 the condition was belatedly recognised in Britain by Moxon who gave an excellent account:

'The diagnostic characters of insular sclerosis are - peculiar trembling of the head and limbs during movements, ceasing when the part is supported.

A peculiar affection of the speech, so that syllables are uttered with morbid distinctness of accent.

The intellect, and control of the emotions ultimately somewhat impaired without morbid delusions or morbid moral aberration. When these conditions exist in any patient, it is certain that patient has insular patches of grey change scattered throughout the brain and spinal cord.'

Moxon described numbness, urinary and mental symptoms:

'Escape of urine occurred late.'

Enfeeblement of mind included 'laughing incontinently and ... weeping is equally out of just relation to its proper causes ... Hopefulness at one time and depression at another ...'

He recognised [17] the course of illness, early remissions and the disseminated sclerotic patches:

'the disease belongs to the climax of life (25-45), its duration is very variable and may be prolonged over 
many years ... mild scarcely recognisable for $5,8,10$ or more (years) ...

disabling characters of it scattered in a broadcast style, spherical or rounded or oval patches of grey material, considerably harder than the rest of the brain substance' [18].

Astutely he noted 'a conspicuous vessel in the centre of a patch ...' perhaps predicting the later recognition of its immunological features and the importance of vessels in the early disruption of the endothelial blood-brain barrier.

Lord Brain published a critical and precise review of the disease and its history in 1930 [19], which repays close study. A comprehensive monograph, Multiple Sclerosis was written by Douglas McAlpine, Nigel Compston and Charles Lumsden. Alastair Compston and collaborators edited the 3rd edition in 1998.
Using Camillo Golgi and Santiago Ramon y Cajal's, new staining techniques with silver and gold to enhance the microscopic visibility of neurones, James Dawson at Edinburgh in 1916 examined with remarkable attention to detail a series of MS brains. He gave a full account of the neuropathology and observed the inflammatory damage to myelin and blood vessels.

Thomas Rivers in 1935 showed that nerve tissue, not viruses, produced an MS-like illness. His animal model created EAE or Experimental Allergic Encephalomyelitis, later shown [20] to have little relation to modern theories of human autoimmunity and immunosuppressive treatments for MS. The eminent clinician, WB Matthews [21] clarified the position:

'MS is exclusively a human disease ... and there is no natural equivalent in animals...'

\section{References}

1 Firth D: The Case of Augustus D'Este. Cambridge, Cambridge University Press 1948.

2 Fredrikson S, Kam-Hansen S: The 150-year anniversary of multiple sclerosis: does its early history give an aetiological clue? Perspect Biol Med 1989;32:238.

3 Compston A: The 150th anniversary of the first depiction of the lesions of multiple sclerosis. $\mathrm{J}$ Neurol Neurosurg Psychiatry 1988;51:12501253 .

4 Dawson JW: The histology of disseminated sclerosis. Trans Roy Soc Edinb 1916;50:517.

$\checkmark 5$ McDonald WI: Physicians, subsequence and consequence. J Neurol Neurosurg Psychiatry 1999;67:282-289.

6 McKenzie W: A Practical Treatise on Diseases of the Eye, ed 3. London, Longman, 1840.

7 Carswell R: Illustrations of the Elementary Forms of Disease. London, Longman, 1838, P1 1V, fig 1 .
8 Cruveilhier J: L'Anatomie pathologique du corps humain; descriptions avec figures lithographiées et coloriées: diverses alterations morbides dont le corps humain est susceptible. Paris, Ballière, 1829-1842, vol 2; liv 32, Pl 2, pp 19-24; liv 38, P1 5, pp 1-4.

$\checkmark 9$ Flamm E: The neurology of Jean Cruveilhier. Med Hist 1973; 17:343-355.

10 Rindfleisch E: Histologisches Detail zu der grauen Degeneration von Gehirn und Rückenmark. Arch Pathol Anat Physiol 1863;26:474483.

11 Charcot JM: Lectures on the diseases of the nervous system delivered at La Salpêtrière (transl from French). London, The New Sydenham Society, 1877, pp 170-177; 182-202.

12 Marie P: Lectures on diseases of the spinal cord (transl from French). London, The New Sydenham Society, 1895, p 103.

13 Charcot JM: Histologie de la sclérose en plaques. Gaz Hop (Paris) 1868;41:554, 557 558, 566.

14 Charcot M: Lectures on Diseases of the Nervous System (transl from French). London, The New Sydenham Society, 1881, vol 1, p 214.
15 McDonald WI: The dynamics of multiple sclerosis: the Charcot lecture. J Neurol 1993;240: 28-30.

16 Frith JA: History of multiple sclerosis: an Australian perspective. Clin Exp Neurol 1988;25: 7-16.

17 Pearce JMS: Some British contributions to the history of multiple sclerosis; in: Fragments of Neurological History. London, Imperial College Press, 2003, pp 290-293.

18 Moxon W: Eight cases of insular sclerosis of the brain and spinal chord. Guys Hosp Rep 1875; 20:437-480.

19 Brain WR: Critical review: disseminating sclerosis. Q J Med 1930:23;343-391.

20 Field EJ (ed). Multiple Sclerosis: A Critical Conspectus. Lancaster, MTP, 1977.

21 Matthews WB: Multiple Sclerosis - The Facts. Oxford, Oxford University Press, 1978. 